\title{
Sensitivity of anti-SARS-CoV-2 serological assays in a high-prevalence setting
}

\author{
Lisa Müller ${ }^{1}(\mathbb{D})$ Philipp Niklas Ostermann ${ }^{1}$ (i) $\cdot$ Andreas Walker $^{1} \cdot$ Tobias Wienemann $^{2} \cdot$ Alexander Mertens $^{3}$. \\ Ortwin Adams $^{1}$ - Marcel Andree ${ }^{1}$. Sandra Hauka ${ }^{1}$. Nadine Lübke ${ }^{1}$ - Verena Keitel ${ }^{3}$ - Ingo Drexler ${ }^{1}$. \\ Veronica Di Cristanziano ${ }^{4}$. Derik Franz Hermsen ${ }^{5} \cdot$ Rolf Kaiser $^{4}$. Friedrich Boege ${ }^{5}$. Florian Klein ${ }^{4} \cdot$ Heiner Schaal $^{1}$ (D) \\ Jörg Timm ${ }^{1}$ (1) - Tina Senff ${ }^{1}$ (D)
}

Received: 29 September 2020 / Accepted: 17 January 2021 / Published online: 3 February 2021

(C) The Author(s) 2021

\begin{abstract}
Evaluation and power of seroprevalence studies depend on the performed serological assays. The aim of this study was to assess four commercial serological tests from EUROIMMUN, DiaSorin, Abbott, and Roche as well as an in-house immunofluorescence and neutralization test for their capability to identify SARS-CoV-2 seropositive individuals in a high-prevalence setting. Therefore, 42 social and working contacts of a German super-spreader were tested. Consistent with a high-prevalence setting, 26 of 42 were SARS-CoV-2 seropositive by neutralization test (NT), and immunofluorescence test (IFT) confirmed 23 of these 26 positive test results (NT $61.9 \%$ and IFT 54.8\% seroprevalence). Four commercial assays detected anti-SARS-CoV-2 antibodies in 33.3-40.5\% individuals. Besides an overall discrepancy between the NT and the commercial assays regarding their sensitivity, this study revealed that commercial SARS-CoV-2 spike-based assays are better to predict the neutralization titer than nucleoprotein-based assays are.
\end{abstract}

Keywords SARS-CoV-2 $\cdot$ COVID-19 $\cdot$ Serology $\cdot$ Neutralizing antibodies $\cdot$ Immunofluorescence test $\cdot$ Seroprevalence

Lisa Müller and Philipp Niklas Ostermann contributed equally to this work. Author order was determined on the basis of seniority.

Highlights

- Forty-two contacts of a COVID-19 index patient with 26 individuals showing neutralizing antibodies

- Neutralization test suggests low sensitivity of commercial anti-SARS$\mathrm{CoV}-2$ tests.

- Higher sensitivity of nucleocapsid-restricted assays

- Stronger correlation of spike-based assays with neutralization capacity

Author order was determined on the basis of seniority.

Jörg Timm

timm@uni-duesseldorf.de

Tina Senff

senff@hhu.de

1 Institute of Virology, University Hospital Düsseldorf, Heinrich Heine University Düsseldorf, 40225 Düsseldorf, Germany

2 Institute of Medical Microbiology and Hospital Hygiene, Heinrich Heine University Düsseldorf, 40255 Düsseldorf, Germany
3 Department of Gastroenterology, Hepatology and Infectious Diseases, University Hospital Düsseldorf, Heinrich Heine University Düsseldorf, 40255 Düsseldorf, Germany

4 Institute of Virology, Faculty of Medicine and University Hospital of Cologne, University of Cologne, 50935 Cologne, Germany

5 Institute of Clinical Chemistry and Laboratory Diagnostics, Medical Faculty, University Düsseldorf, 40255 Düsseldorf, Germany 


\section{Introduction}

In December 2019, a new coronavirus, severe acute respiratory syndrome coronavirus 2 (SARS-CoV-2), emerged in China and its pandemic spread resulted in more than 30 million infected people according to the World Health Organization [1-3]. Sensitive serological SARS-CoV-2 assays are of great importance for seroprevalence studies and retrospective diagnosis of SARS-CoV-2 infections and aide in estimating prevalence and incidence [4]. Additionally, these assays are necessary to identify donors for convalescent plasma therapy and to determine antibody titers to assess induced immunity after vaccination [5]. Here, we assess and compare different commercial serological tests as well as an in-house neutralization and immunofluorescence test (IFT) in the context of a SARS$\mathrm{CoV}-2$ high-prevalence setting.

\section{Material and methods}

\section{Patients}

Serum samples from 42 non-randomized volunteers from the same local area were collected on April 9, 2020. Individuals had direct or indirect contact to a German index patient with a PCR-confirmed SARS-CoV-2 infection and hospitalization on April 24. Previous SARS-CoV-2 PCR testing and symptoms and their onset were queried. Due to the small cohort size, a classification of the severity of symptoms in PCRconfirmed cases was not performed. Health authorities tested 26 of 42 by PCR before sample collection on April 9 with 8 of 26 being SARS-CoV-2 PCR positive.

\section{Ethical statement}

The study was approved by the local ethics committee (study number: 5350). Written informed consent was given from each included individual.

\section{Commercially available anti-SARS-CoV-2 test systems}

Samples were tested for anti-SARS-CoV-2 antibodies with four commercially available test systems: EUROIMMUN (EI), Roche, Abbott, and DiaSorin, recognizing either SARS-CoV-2 virus spike (S) protein or nucleocapsid (N) antibodies. Euroimmun ELISA directed against the S1 domain of the spike protein detecting $\operatorname{IgA}$ and $\operatorname{IgG}$ was performed on the Euroimmune Analyzer I-2P according to manufacturer's instructions. OD ratio $\geq 1.1$ for $\operatorname{IgA}$ and $\operatorname{IgG}$ was considered positive, $\leq 0.8$ as negative, and $\geq 0.8 \leq 1.1$ as borderline. Upper detection limits were OD ratio $=7$ for $\operatorname{IgA}$ and $\mathrm{OD}$ ratio $=10$ for $\mathrm{IgG}$. IgG antibodies against S1/S2 domains of SARSCoV-2 spike were detected through chemiluminescent immunoassay (CLIA) from DiaSorin on a LIAISONX. SARS-CoV-2 S1/S2 IgG antibody concentrations are given as arbitrary units $(\mathrm{AU} / \mathrm{ml})$. Samples $<12 \mathrm{AU} / \mathrm{ml}$ were interpreted as negative, $12-15 \mathrm{AU} / \mathrm{ml}$ as borderline, and $\geq 15$ $\mathrm{AU} / \mathrm{ml}$ as positive. The Elecsys ${ }^{\circledR}$ anti-SARS-CoV-2 electrochemiluminescence immunoassay (ECLIA) from Roche was performed on a cobas e 801 immunoassay analyzer for the detection of antibodies (including $\mathrm{IgG}$ ) against SARS$\mathrm{CoV}-2 \mathrm{~N}$ antigen. Cut-off was based on the measurement of two calculators, and the result was given as signal sample to cutoff (COI). COI $<1.0$ is negative for anti-SARS-CoV-2 antibodies and $\mathrm{COI} \geq 1.0$ is considered positive. The SARS$\mathrm{CoV}-2 \mathrm{IgG}$ chemiluminescent microparticle immunoassay (CMIA) from Abbott performed on an ARCHITECT i2000 SR detects IgG antibodies to N. The relation of chemiluminescent RLU and the calibrator is given as the calculated index $(\mathrm{S} / \mathrm{C})$. An index $(\mathrm{S} / \mathrm{C}) \geq 1.4$ is considered positive and $<1.4$ as negative.

\section{Cell culture}

Vero cells (ATCC-CCL-81 obtained from LGC Standards) were grown in Dulbecco's modified essential medium (DMEM) with $1 \%$ penicillin and streptomycin (Gibco, 100 $\mathrm{U} / \mathrm{ml}$ penicillin and $100 \mu \mathrm{g} / \mathrm{ml}$ streptomycin) and $2 \%$ fetal calf serum (FCS, PAN Biotech) and were cultured in a $5 \% \mathrm{CO}_{2}$ humified atmosphere at $37^{\circ} \mathrm{C}$.

\section{SARS-CoV-2 virus isolate}

For the neutralization test, SARS-CoV-2 isolate NRW-42 was used [6]. The complete sequence of this virus isolate is online (EPI ISL_425126). There is a single-nucleotide exchange in the spike ORF between the Wuhan-Hu1 reference sequence and the NRW-42 sequence used for NT and IFT. The isolate carries a $A>G$ mutation within the Spike gene at nucleotide position 23,403 which is located within the S1 domain, but outside of the RBD or RBM motif respectively. There is no nucleotide exchange in the nucleocapsid ORF. Unfortunately, antigenic identity of sequences used in the commercial tests is unavailable.

\section{Neutralization test}

To detect SARS-CoV-2-neutralizing antibodies, a modified neutralization test was performed [7]. Sera were heat inactivated for $30 \mathrm{~min}$ at $56{ }^{\circ} \mathrm{C}$ and briefly centrifuged. Initial 1:5 dilutions were prepared in duplicate per patient followed by twofold serial dilutions performed in $50-\mu \mathrm{l}$ volume with DMEM (1\% penicillin and streptomycin, $2 \% \mathrm{FCS}$ ). A total of $50 \mu \mathrm{l}$ of SARS-CoV-2 stock dilution (final conc. $\mathrm{TCID}_{50}$ of 50) was added to the sera dilutions, control sera, and virus only controls (no serum added). Cell-free plates 
were pre-incubated at $37^{\circ} \mathrm{C}$ for $1 \mathrm{~h}$. Afterwards, $100 \mu \mathrm{l}$ of cell suspension containing $7 \times 10^{4} / \mathrm{ml}$ Vero cells was added to samples and cell growth controls. Plates were incubated for 4 days. By microscopic inspection, the titer of neutralizing antibodies was determined as the highest serum dilution without a cytopathic effect (CPE). The reciprocal of the serum dilution is given as the NT titer. A neutralization titer of $\geq 20$ was considered positive. Samples from three individuals with documented coronavirus HCoV-229E, HCoV-OC43, and HCoV-NL63 infections served as controls for cross reactivity $(\mathrm{NT}$ titer $=0)$.

\section{Immunofluorescence test}

Vero cells were seeded at a density of $10^{4}$ cells per well into a 48-well plate. After $24 \mathrm{~h}$, cells were infected with SARSCoV-2 NRW-42 isolate (TCID 50 of 50) except for controls. At 2 dpi, fixation was performed with ice-cold methanol for $20 \mathrm{~min}$ at $-20{ }^{\circ} \mathrm{C}$. Subsequently, cells were washed three times with PBS, permeabilized with $0.5 \%$ Triton X-100 in PBS for $20 \mathrm{~min}$, and washed again three times. Sera were diluted 1:40 in PBS containing 5\% FCS. Cells were incubated in $200-\mu \mathrm{l}$ patient serum, for $2 \mathrm{~h}$ at room temperature. Two SARS-CoV-2-infected wells and one well with uninfected cells were used per patient. Positive control serum was obtained from a patient with high levels of anti-SARS-CoV-2 IgG. After washing, cells were incubated for $1 \mathrm{~h}$ at room temperature with anti-human IgG FITC conjugate (Life Technologies, USA) diluted 1:40 in PBS containing 0.1\% Evans blue and $5 \%$ FCS. Cells were washed three times with PBS and analyzed by microscopy. IFT results were independently evaluated by two staff members. Positive results indicated IFT titer $\geq 40$.

\section{Statistical analysis}

GraphPad Prism version 8.0.2 was used for statistical analysis. Pearson correlation analysis was used to assess correlation between serological assays. Good correlation was assumed if $r \geq 0.5$ and moderate if $r \geq 0.3$ in combination with $p \leq 0.05$. One-way analysis of variance (ANOVA) was performed for comparison between groups after checking for normal distribution. The respective $p$ values are given as $* * p \leq 0.01$ and $* * * p \leq 0.001$.

\section{Results}

\section{SARS-CoV-2 high-prevalence setting-social and working contacts of a German index patient}

On 24 February 2020, a patient from the Heinsberg District, Germany was diagnosed SARS-CoV-2 positive by RT-
PCR. By February 28, contact tracing from health authorities identified 37 secondary cases. In addition, this index patient was associated with a super spreading event held on 15 February 2020 , and $>1000$ SARS-CoV-2 cases were linked to this event [8].

To assess different serological tests for detection of antiSARS-CoV-2 antibodies in the context of a high-prevalence setting, blood samples of 42 social and working contacts of this index patient were collected on April 9, 2020 and subsequently analyzed. Importantly, since the index patient was hospitalized on February 24, contact to this patient must have occurred at least 6 weeks before sample collection. Despite reported symptom onset was around 10 days prior to admission to hospital, the patient continued to actively participate in social and business life.

The study population contained slightly more females than males $(26 / 1661.9 \%, 38.1 \%)$ and individuals were aged between 18 and 70 years (median 44). Although only eight of the 42 individuals were previously tested positive for SARSCoV-2-RNA by RT-PCR, 26 described symptoms including fever $(38.5 \%)$, cough $(65.4 \%)$, fatigue $(50 \%)$, shortness of breath, or difficulty of breathing (30.8\%) while 16 reported no symptoms (Table S1).

\section{Determining SARS-CoV-2 seroprevalence by an in- house SARS-CoV-2 immunofluorescence and neutral- ization test}

First, an in-house neutralization test was performed to identify SARS-CoV-2 seropositive individuals in the described study population. The neutralization test, including the cut-off NT titer of $\geq 20$, was previously validated with 30 SARS-CoV-2 negative sera (NT titer $<10$; PCR negative or sampled before December 2019) and 25 positive sera from RT-PCR-positive individuals (NT titer 20 to 10,240) and resulting NT titers reflected the current literature $[9,10]$.

Neutralizing antibodies (NT titers $\geq 20$ ) were detected in 26 of the 42 serum samples (61.9\%). Besides the RT-PCRconfirmed SARS-CoV-2 cases $(n=8), 13$ out of the 19 symptomatic (68.4\%) and 5 of the 15 asymptomatic (33.3\%) individuals had neutralizing antibodies (Table S2). Neutralizing antibody levels in asymptomatic individuals were significantly lower compared to PCR-confirmed cases ( $p \leq 0.01$, Fig. 1).

To support the NT-based finding of a high SARS-CoV-2 seroprevalence in our study population, an in-house immunofluorescence test (IFT) detecting anti-SARS-CoV-2 IgG was performed. Of the 26 sera positive in the neutralization test, 23 were also positive in the IFT (sensitivity $88.5 \%, 95 \% \mathrm{CI}$ [0.710-0.960]). Additionally, negative IFT results were associated with low $(\leq 40)$ NT titers. This overall supports the finding of a high seroprevalence in our study population as determined by NT. 

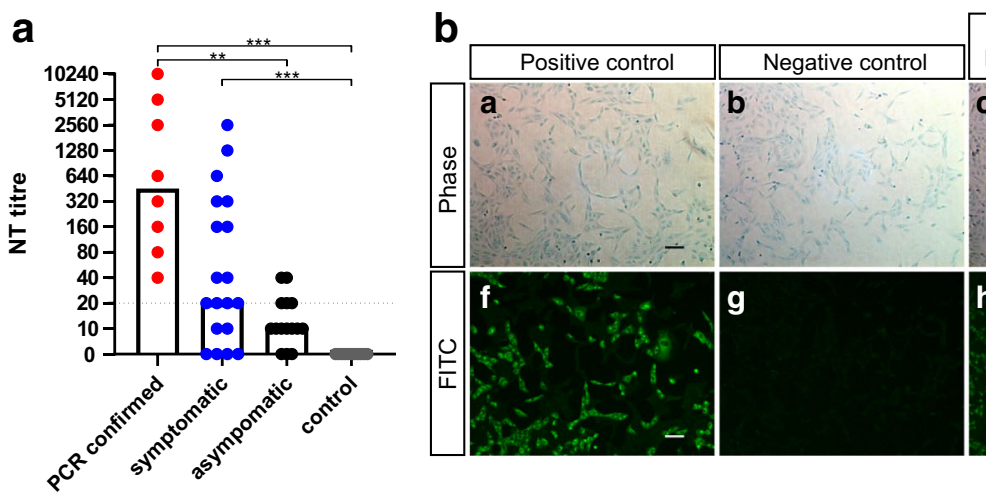

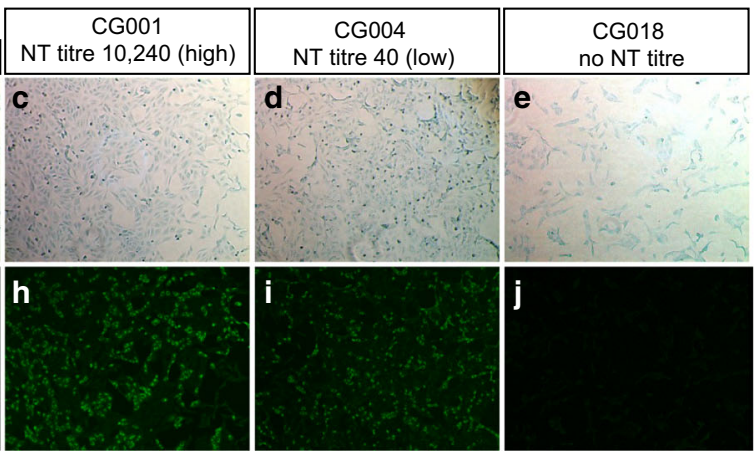

Fig. 1 SARS-CoV-2-neutralizing antibodies stratified according to status of study participants and exemplary immunofluorescence test results, Heinsberg District, Germany, April $2020(n=42)$. FITC: fluorescein isothiocyanate; NT: neutralization test. a Neutralization test results of 42 individuals grouped by their status in PCR confirmed (red), symptomatic (blue), and asymptomatic (black) and 11 control sera from healthy individuals sampled before December 2019. The reciprocal of the NT titer is depicted, and bars represent the respective median. The cut-off

\section{Sensitivity of commercial high-throughput SARS-CoV- 2 antibody assays}

Based on in-house NT results, supported by IFT, anti-SARSCoV-2 antibodies were found in 26 of the 42 sera. Since both methods are time-consuming and labor-intensive, suitability of antibody testing was analyzed with four different commercially available automated serological test systems targeting either the nucleocapsid protein $(\mathrm{N})$ or the spike protein $(\mathrm{S})$ of SARS-CoV-2 (Table 1, Figure S1/S2).

Our study included the (i) EUROIMMUN(EI)-anti-SARSCoV-2 IgA and IgG ELISA test, which contains the S1 subunit of the spike protein (EI S1 IgG or EI S1 IgA); (ii) the LIAISON® SARS-CoV-2 S1/S2 IgG CLIA test, containing the $\mathrm{S} 1$ and $\mathrm{S} 2$ domain of the spike protein (DiaSorin S1/S2 IgG); (iii.)the SARS-CoV-2 IgG CMIA from Abbott detecting anti-nucleocapsid IgG antibodies (Abbott N IgG) and (iv) the Elecsys ${ }^{\circledR}$ anti-SARS-CoV-2 ECLIA test from Roche which uses biotinylated and ruthenylated nucleocapsid antigen for the determination of antibodies against SARS-CoV-2 (Roche $\mathrm{N} \mathrm{Ab}$ ). For comparison, test results from these commercially available assays were evaluated in relation to the previously described in-house NT.

Of the 26 sera that were tested positive by NT, 12 were also tested positive with the EI S1 IgG or IgA assay, while all 16 NT negative sera have been identified as negative. Of note, 10 of the 26 individuals were positive in the EI S1 IgG as well as the EI S1 IgA test (Table 1). Although the DiaSorin S1/S2 IgG test identified 16 of the 26 NT-positive individuals as positive, 5 of the 16 NT negative individuals were tested positive as well. The Abbott N IgG test detected 16 positive individuals while the Roche N Ab test determined 17 of the 26 NTpositive individuals as positive. In both tests, none of the NT negative sera was above the respective cut-off. Thus, the was defined as $\geq 20$. One-way ANOVA was used to compare groups ( $* * p$ $\leq 0.01$ and $* * * p \leq 0.001)$. b Exemplary anti-SARS-CoV-2 IgG immunofluorescence test results of 3 out of 42 tested individuals. Phase contrast $(\mathrm{a}-\mathrm{e})$ and FITC fluorescence detected at $488 \mathrm{~nm}(\mathrm{f}-\mathrm{j})$. Serum of a severe hospitalized COVID-19 case served as a positive control $(a+f)$ and $(b+g)$ depict the result of a negative control serum. IFT results from a patient with a high NT titer (c+h; NT titer 10,240), a low NT titer (d+i NT titer $40)$, and no neutralization potential $(\mathrm{e}+\mathrm{j})$. Scale bar is $100 \mu \mathrm{m}$

negative agreement between the NT and EI S1 IgG or IgA test, the Roche $\mathrm{N} \mathrm{Ab}$ assay, and the Abbott $\mathrm{N} \mathrm{IgG}$ test was $100 \%$. However, the false-positive rate of the DiaSorin S1/S2 IgG assay was $31.3 \%$.

Taking the performed in-house NT as standard, the EI S1 IgG or IgA test had the lowest sensitivity $(46.2 \%, 95 \% \mathrm{CI}$ [0.355-0.712]; IgA and/or IgG positive 53.8\%). The sensitivity of the Abbott N IgG assay as well as the DiaSorin S1/ S2 IgG test was $61.54 \%$ (95\% CI [0.425-0.776]) in relation to NT results. Notably, the Roche N Ab assay had the highest sensitivity with $65.4 \%$ (95\% CI [0.462-0.806]) (Table 2). Taken together, the N-restricted tests showed a better sensitivity compared to the S-restricted tests. Nevertheless, the use of the commercially available automated serological test systems described herein would result in the reporting of a lower seroprevalence compared to the in-house neutralization test.

\section{Correlation of commercial SARS-CoV-2 antibody assay results with neutralization ability}

To assess which SARS-CoV-2 antibody test platforms are more suitable for predicting neutralizing antibody levels, correlations of commercial SARS-CoV-2 antibody assay results with neutralization test results were determined. The neutralization titer, based on the in-house neutralization test, correlated strongly with all spike antigen-based antibody tests (EI $\mathrm{S} 1 \mathrm{IgA} r=0.7625$; EI S1 IgG $r=0.6886$; DiaSorin S1/S2 IgG $r=0.5641$ ) (Fig. 2). The weaker correlation of the commercial N-test systems (Abbott N IgG $r=0.4579$ and Roche N Ab $r=$ 0.3523 ) with the neutralizing antibody titers indicated that $\mathrm{S}$ based systems are more likely to be predictive for functional antibodies. 
Table 1 Patient characteristics and serological test results of all anti-SARS-CoV-2 assays performed in this study, Heinsberg District, Germany, April $2020(n=42)$

\begin{tabular}{|c|c|c|c|c|c|c|c|c|c|c|c|}
\hline \multirow[t]{2}{*}{ Sample ID } & \multirow[t]{2}{*}{ Age in years } & \multirow[t]{2}{*}{ Gender } & \multirow[t]{2}{*}{ PCR } & \multirow[t]{2}{*}{ Status } & \multirow{2}{*}{$\begin{array}{l}\text { Reciprocal } \\
\text { NT titer }\end{array}$} & \multirow{2}{*}{$\begin{array}{l}\text { IgG } \\
\text { IFT }\end{array}$} & \multicolumn{2}{|c|}{ EUROIMMUN } & \multirow{2}{*}{$\begin{array}{l}\text { DiaSorin } \\
\text { CLIA IgG } \\
\text { (AU/ml)* }\end{array}$} & \multirow{2}{*}{$\begin{array}{l}\text { Roche } \\
\text { ECLIA } \\
(\mathrm{COI})^{* *}\end{array}$} & \multirow{2}{*}{$\begin{array}{l}\text { Abbott } \\
\text { CMIA IgG } \\
\text { (index S/C)** }\end{array}$} \\
\hline & & & & & & & $\begin{array}{l}\text { ELISA IgA } \\
\text { (OD ratio)* }\end{array}$ & $\begin{array}{l}\text { ELISA IgG } \\
\text { (OD ratio)* }\end{array}$ & & & \\
\hline CG001 & 50 & $\mathrm{~m}$ & pos & sym & 10,240 & ++ & $>7$ & 8,68 & 80.7 & 18.8 & 4.99 \\
\hline CG005 & 46 & $\mathrm{f}$ & pos & sym & 5120 & + & 4.36 & $>10$ & 372 & 85.1 & 8.31 \\
\hline CG007 & 59 & $\mathrm{~m}$ & pos & sym & 2560 & ++ & $>7$ & 9,55 & 128 & 57.1 & 9.20 \\
\hline CG012 & 50 & $\mathrm{f}$ & pos & as & 40 & + & 0.24 & 0,62 & 12.2 & 0.1 & 0.06 \\
\hline CG015 & 54 & $\mathrm{~m}$ & pos & sym & 320 & + & 2.11 & 0,56 & 16.2 & 29.2 & 4.34 \\
\hline CG031 & 29 & $\mathrm{~m}$ & pos & sym & 80 & + & 3.41 & 4,84 & 68.4 & 55.7 & 4.72 \\
\hline CG042 & 24 & $\mathrm{f}$ & pos & sym & 640 & + & 4.55 & 6,63 & 82.8 & 23.4 & 3.75 \\
\hline CG043 & 43 & $\mathrm{~m}$ & pos & sym & 160 & + & 0.4 & 2,15 & 63.4 & 68.1 & 6.76 \\
\hline CG002 & 45 & $\mathrm{f}$ & neg & sym & 10 & - & 0.51 & 0,16 & 4.84 & $<0.1$ & 0.02 \\
\hline CG003 & 43 & $\mathrm{~m}$ & neg & sym & 20 & + & 0.58 & 0,39 & 6.57 & 4.1 & 1.44 \\
\hline CG004 & 43 & $\mathrm{f}$ & neg & sym & 40 & + & 0.43 & 0,9 & 12.6 & 1 & 3.69 \\
\hline CG006 & 55 & $\mathrm{f}$ & neg & sym & 10 & - & 0.3 & 0,21 & $<3.8$ & $<0.1$ & 0.02 \\
\hline CG009 & 25 & $\mathrm{~m}$ & neg & sym & 0 & - & 0.29 & 0,22 & 14.4 & $<0.1$ & 0.03 \\
\hline CG011 & 18 & $\mathrm{f}$ & $\mathrm{n} / \mathrm{a}$ & sym & 0 & - & 0.33 & 0,32 & 10.6 & $<0.1$ & 0.04 \\
\hline CG013 & 43 & $\mathrm{f}$ & $\mathrm{n} / \mathrm{a}$ & sym & 160 & + & 0.15 & 0,18 & 13.3 & $<0.1$ & 0.02 \\
\hline CG014 & 55 & $\mathrm{f}$ & neg & sym & 2560 & ++ & 1.49 & 8,66 & 105 & 66.9 & 8.07 \\
\hline CG016 & 55 & $\mathrm{f}$ & neg & sym & 1280 & + & 1.19 & 1,81 & 30.7 & 96.1 & 9.44 \\
\hline CG017 & 59 & $\mathrm{~m}$ & neg & sym & 160 & + & 0.54 & 0,97 & 10.2 & 22.2 & 4.60 \\
\hline CG020 & 38 & $\mathrm{f}$ & neg & sym & 320 & + & 1.11 & 7,84 & 123 & 75.9 & 9.03 \\
\hline CG021 & 39 & $\mathrm{~m}$ & $\mathrm{n} / \mathrm{a}$ & sym & 20 & - & 0.74 & 0,24 & 18.8 & $<0.1$ & 0.02 \\
\hline CG022 & 41 & $\mathrm{~m}$ & neg & sym & 640 & + & 0.68 & 4,47 & 60.6 & 91 & 8.74 \\
\hline CG026 & 22 & $\mathrm{f}$ & neg & sym & 0 & - & 0.2 & 0,29 & 16.5 & $<0.1$ & 0.01 \\
\hline CG028 & 22 & $\mathrm{f}$ & $\mathrm{n} / \mathrm{a}$ & sym & 0 & - & 0.18 & 0,27 & 11.2 & $<0.1$ & 0.01 \\
\hline CG032 & 27 & $\mathrm{f}$ & $\mathrm{n} / \mathrm{a}$ & sym & 40 & + & 1.57 & 3,97 & 79.5 & 10.3 & 2.17 \\
\hline CG033 & 29 & $\mathrm{f}$ & $\mathrm{n} / \mathrm{a}$ & sym & 20 & + & 0.12 & 0,21 & 11.2 & $<0.1$ & 0.12 \\
\hline CG040 & 23 & $\mathrm{f}$ & $\mathrm{n} / \mathrm{a}$ & sym & 320 & + & 1.32 & 3,26 & 32.4 & 12 & 3.29 \\
\hline CG044 & 37 & $\mathrm{f}$ & neg & sym & 20 & + & 1.41 & 1,04 & 18 & 1.5 & 1.17 \\
\hline CG008 & 23 & $\mathrm{f}$ & neg & as & 10 & - & 0.3 & 0,21 & 8.15 & $<0.1$ & 0.06 \\
\hline CG010 & 30 & $\mathrm{f}$ & neg & as & 10 & - & 0.38 & 0,18 & 6.5 & 0.1 & 0.02 \\
\hline CG018 & 46 & $\mathrm{~m}$ & $\mathrm{n} / \mathrm{a}$ & as & 0 & - & 0.27 & 0,15 & 13.5 & $<0.1$ & 0.19 \\
\hline CG019 & 50 & $\mathrm{f}$ & $\mathrm{n} / \mathrm{a}$ & as & 10 & - & 0.3 & 0,31 & $<3.8$ & $<0.1$ & 0.02 \\
\hline CG023 & 49 & $\mathrm{~m}$ & $\mathrm{n} / \mathrm{a}$ & as & 10 & - & 0.45 & 0,28 & 11.6 & $<0.1$ & 0.01 \\
\hline CG024 & 46 & $\mathrm{f}$ & $\mathrm{n} / \mathrm{a}$ & as & 10 & - & 0.19 & 0,17 & $<3.8$ & $<0.1$ & 0.03 \\
\hline CG025 & 70 & $\mathrm{f}$ & neg & as & 40 & - & 0.19 & 0,18 & 10.8 & $<0.1$ & 0.02 \\
\hline CG027 & 47 & $\mathrm{f}$ & neg & as & 20 & + & 0.43 & 0,15 & 10.9 & $<0.1$ & 0.01 \\
\hline CG029 & 69 & $\mathrm{~m}$ & $\mathrm{n} / \mathrm{a}$ & as & 40 & - & 0.21 & 0,17 & 22.3 & $<0.1$ & 0.02 \\
\hline CG030 & 65 & $\mathrm{f}$ & $\mathrm{n} / \mathrm{a}$ & as & 0 & - & 0.13 & 0,18 & 16.3 & $<0.1$ & 0.02 \\
\hline CG034 & 55 & $\mathrm{f}$ & neg & as & 0 & - & 0.09 & 0,18 & 23.5 & $<0.1$ & 0.01 \\
\hline CG035 & 59 & $\mathrm{~m}$ & neg & as & 10 & - & 0.19 & 0,2 & 16.3 & $<0.1$ & 0.02 \\
\hline CG036 & 31 & $\mathrm{~m}$ & $\mathrm{n} / \mathrm{a}$ & as & 10 & - & 0.44 & 0,23 & 20.4 & $<0.1$ & 0.01 \\
\hline CG037 & 25 & $\mathrm{f}$ & $\mathrm{n} / \mathrm{a}$ & as & 20 & + & 0.09 & 0,17 & $<3.8$ & $<0.1$ & 0.04 \\
\hline CG041 & 54 & $\mathrm{~m}$ & $\mathrm{n} / \mathrm{a}$ & as & 20 & + & 0.3 & 0.15 & 12.5 & $<0.1$ & 0.01 \\
\hline \multicolumn{12}{|c|}{ Cohort summary $n=42$} \\
\hline & & & \multirow{3}{*}{\multicolumn{2}{|c|}{$\begin{array}{l}\text { Positive, } n \\
\text { Borderline, } n \\
\text { Negative, } n \\
\text { Seropositive }\end{array}$}} & $\begin{array}{l}26 \\
\mathrm{n} / \mathrm{a}\end{array}$ & $\begin{array}{l}23 \\
\mathrm{n} / \mathrm{a}\end{array}$ & $\begin{array}{l}12 \\
0\end{array}$ & $\begin{array}{l}12 \\
3\end{array}$ & $\begin{array}{l}21 \\
6\end{array}$ & $\begin{array}{l}17 \\
\mathrm{n} / \mathrm{a}\end{array}$ & $\begin{array}{l}10 \\
\mathrm{n} / \mathrm{a}\end{array}$ \\
\hline & & & & & & 19 & 30 & 27 & & 25 & 26 \\
\hline & & & & & $(61.9 \%)$ & $(54.8 \%)$ & $(28.6 \%)$ & $(28.6 \%)$ & $(50.0 \%)$ & $(40.5 \%)$ & $(38.1 \%)$ \\
\hline
\end{tabular}

Results are defined as positive according to the manufacturer's instructions: OD ratio $\geq 1.1 ; \mathrm{AU} / \mathrm{ml} \geq 15 ; \mathrm{COI} \geq 1.0$; index $(\mathrm{S} / \mathrm{C}) \geq 1.4$

$A U$ arbitrary units; as asymptomatic; COI cut-off index; CMIA chemiluminescent microparticle immunoassay; CLIA chemiluminescent immunoassay; ECLIA electrochemiluminescence immunoassay; ELISA enzyme-linked immunosorbent assay; $f$ female; ID patient identification; IFT immunofluorescence test; $m$ male; $n / a$ not applicable; $N T$ neutralization test; $O D$ optical density; $S / C$ sample/control; sym symptomatic

*Anti-spike

**Anti-nucleocapsid 
Table 2 Performance characteristics of the EUROIMMUN, DiaSorin, Roche, and Abbott SARS-CoV-2 antibody platforms, Heinsberg District, Germany, April $2020(n=26)$

\begin{tabular}{|c|c|c|c|c|c|c|c|}
\hline & & \multicolumn{3}{|c|}{ EUROIMMUN } & \multirow{2}{*}{$\begin{array}{l}\text { DiaSorin } \\
\text { S1/S2 IgG }\end{array}$} & \multirow{2}{*}{$\begin{array}{l}\text { Roche } \\
\mathrm{N} \text { antibodies }\end{array}$} & \multirow{2}{*}{$\begin{array}{l}\text { Abbott } \\
\text { N IgG }\end{array}$} \\
\hline & & S1 IgA & S1 IgG & S1 IgA and/or IgG & & & \\
\hline \multirow[t]{3}{*}{ Overall NT positive $\geq 20$} & $\mathrm{n} / \mathrm{N}$ & $12 / 26$ & $12 / 26$ & $14 / 26$ & $16 / 26$ & $17 / 26$ & $16 / 26$ \\
\hline & Value & 0.462 & 0.462 & 0.538 & 0.615 & 0.654 & 0.615 \\
\hline & $(95 \% \mathrm{CI})$ & $0.288-0.645$ & $0.288-0.645$ & $0.355-0.712$ & $0.425-0.776$ & $0.462-0.806$ & $0.425-0.776$ \\
\hline
\end{tabular}

For sensitivity calculations of the commercial assays, only the NT-positive samples $(\geq 20)$ were used

$C I$ confidence interval; $N$ nucleocapsid; $N T$ : neutralization test; $S$ spike

\section{Discussion}

We assessed and compared the sensitivity of four different available commercial antibody tests EUROIMMUN-antiSARS-CoV-2 IgA and IgG ELISA, LIAISON® SARSCoV-2 S1/S2 IgG (DiaSorin) CLIA, the SARS-CoV-2 IgG CMIA from Abbott, and the Elecsys ${ }^{\circledR}$ anti-SARS-CoV-2 ECLIA test from Roche as well as an in-house immunofluorescence and neutralization test, in a SARS-CoV-2 highprevalence setting. For this, we collected serum samples of close contacts to the NRW index patients at least 6 weeks after possible contact occurred. With respect to serological assays, more than 1 month after a putative infection is sufficient to allow detection of SARS-CoV-2 antibody responses [11, 12]. Various reports suggest that virus-specific IgG levels in positive patients are most reliably detected between 17 days and 8 weeks post infection [12-14].

A peculiarity of this study is that the cohort included 42 individuals who had contact to the NRW index patient at the end of February 2020, a time of uncontained viral spread since health authorities had not yet taken containment measures. Although only 8 individuals were previously tested positive
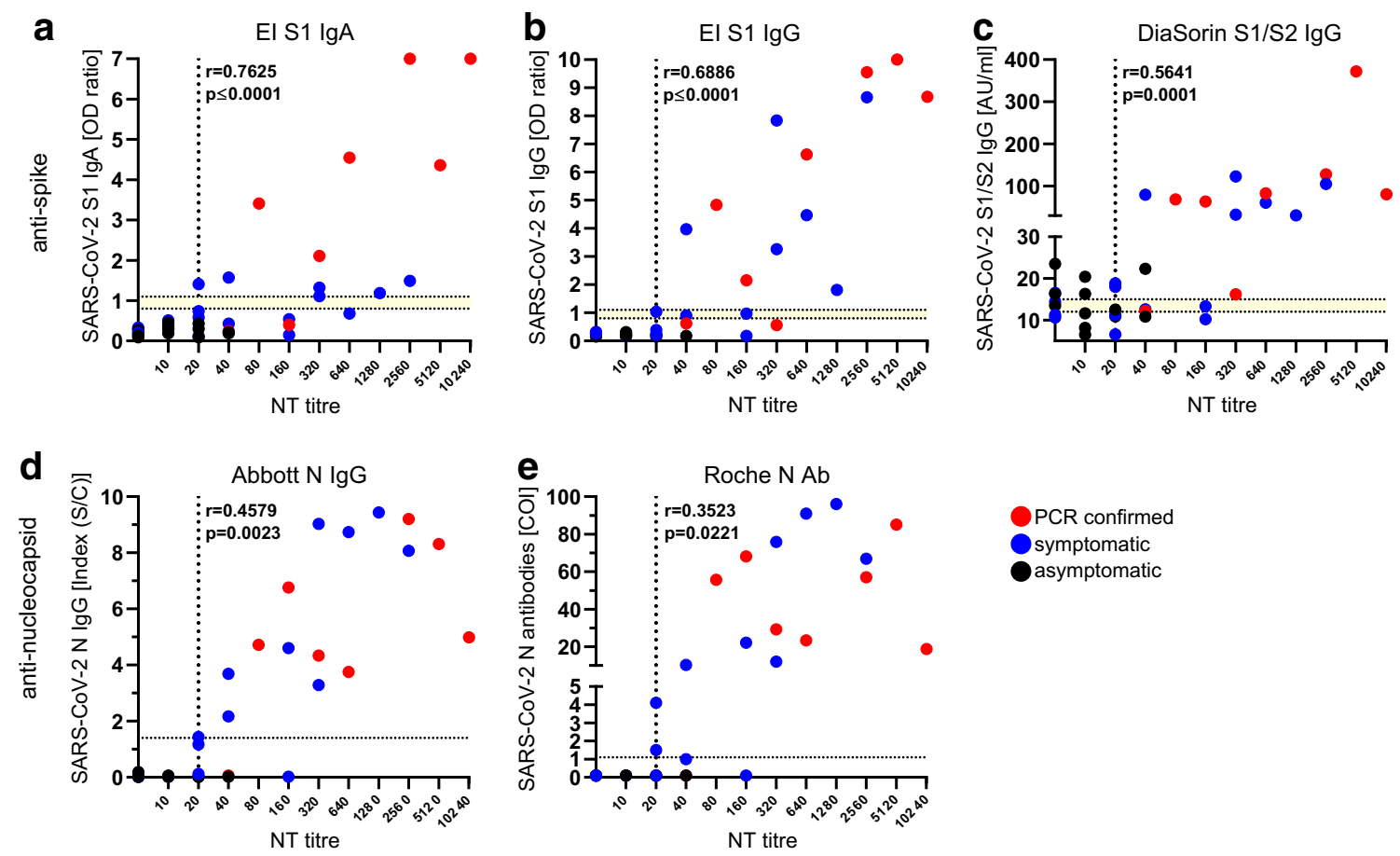

Fig. 2 Correlation between commercial SARS-CoV-2 antibody tests and the neutralization titer, Heinsberg District, Germany, April $2020(n=42)$. AU: arbitrary units; COI: cut-off index; EI: EUROIMMUN; N: nucleocapsid; NT: neutralization test; OD: optical density; $r$ : correlation coefficient; S1: spike domain 1; S2: spike domain 2; S/C: sample/control; SARS-CoV-2: severe acute respiratory syndrome coronavirus 2 . The reciprocal of the NT titer is depicted. RT-PCR-confirmed SARS-CoV-2 infections are depicted in red and symptomatic individuals in blue. All asymptomatic individuals are displayed in black. a and $\mathbf{b}$ EUROIMMUN-anti-SARS-CoV-2 IgA and IgG ELISA (Euroimmun). c LIAISON® SARS-CoV-2 S1/S2 IgG (DiaSorin). d SARS-CoV-2 IgG CMIA (Abbott). e Elecsys ${ }^{\circledR}$ anti-SARS-CoV-2 ECLIA test (Roche). The dotted lines indicate the cut-off values recommended by the respective manufacturer to determine positive and negative test results. The borderline area if applicable is indicated in yellow and the vertical line represents the positive cut-off of an NT titer $\geq 20$ 
for SARS-CoV-2 by PCR, we found that 26 of the 42 individuals had neutralizing antibodies $(61.9 \%)$ in an in-house neutralizing test (NT). This high seroprevalence is consistent with data from a high school in France describing that $40.9 \%$ of pupils, teachers, and the school staff combined had SARSCoV-2 antibodies [15].

The study by Streeck et al. [16], sampling a random cohort of 1007 people from the area where the German Heinsberg outbreak occurred, found an anti-SARS-CoV-2 seroprevalence in the range of $15 \%$. With respect to this lower seroprevalence reported by Streeck et al., it is important to acknowledge the different sampling approaches. Nevertheless, our data suggest that in such a high-prevalence setting, a substantial number of convalescent COVID-19 cases may be missed with commercial serological assays. Although we found a high concordance of immunofluorescence test (IFT) positive with NT-positive individuals (23 of $26 ; 88.5 \%$ 95\% CI [0.710-0.960]), the commercially available SARS-CoV-2 antibody assays from four companies evaluated in this study had led to fewer positive test results, suggesting a lower sensitivity compared to the NT or the IFT in this cohort. These results are in line with Kohmer et al. [17]. Furthermore, this adds to the difference observed between our study and the one of Streeck et al. as only ELISA IgG seropositive sera were analyzed in their NT [16].

Although none of the commercial assays detected more than $65.4 \%$ of SARS-CoV-2 NT-positive individuals, we see a slightly higher sensitivity of nucleocapsid assays compared to assays using spike, which is in line with previous findings [18]. However, since the median time of sera sampling after symptom onset was 43 days, this could not be attributed to an earlier anti-N response as described by Grzelak et al. [19]. Notably, both $\mathrm{N}$-restricted assays gave no false-positive results in our small cohort even though a higher cross reactivity to human coronaviruses (HCoVs) has been proposed [5]. The sensitivity of the assays as reported by the manufacturers ranged between 93.8 and $100 \% \geq 14$ to $>21$ days post symptom onset. However, critical COVID-19 cases seem to mount a more robust antibody response than non-critical hospitalized patients [11]. Accordingly, all assays detected higher antibody levels in the 8 confirmed PCR-positive cases, a group that showed a more severe disease course than the other groups. It is important to note that the sensitivities calculated in the current study refer to a high-prevalence setting with mild and asymptomatic courses and only one non-critical hospitalized patient. In turn, the sensitivity might be insufficient for detection of all mild or asymptomatic cases as in this cohort. A study performed in South Korea found that serological testing of PCR confirmed but asymptomatic patients only identified $71 \%$ positive individuals, while neutralizing antibodies were detectable in all asymptomatic individuals [13].

In line with previous studies, ELISA and CLIA assays detecting anti-S or anti-N antibodies had a mild to strong correlation with neutralization titers [10, 20]. The
EUROIMMUN-anti-SARS-CoV-2 IgA and IgG ELISA tests showed the strongest correlation with antibody function (IgA $r=0.7625, p \leq 0.0001 ; \operatorname{IgG} r=0.6886, p \leq$ $0.0001)$ followed by the LIAISON® SARS-CoV-2 S1/S2 IgG assay $(r=0.5641, p=0.0001)$. In the current study, serological assays detecting spike antibodies showed better correlations, which might be due to the fact that the spike protein is the major target for neutralizing antibodies for related coronaviruses and proposedly as well for SARSCoV-2 [21, 22]. Wu and colleagues as well report that the neutralizing antibody titers correlate with spikebinding antibodies which target the viral S1, RBD, and $\mathrm{S} 2$ regions [23].

Of note, the DiaSorin S1/S2 IgG assay rendered five false-positive results from NT assay-negative samples. This finding might suggest a cross reactivity to other endemic HCoVs, possibly because the spike S2 subunit is more conserved among $\mathrm{HCoVs}$ than the S1 domain, but this needs to be confirmed with further experiments [10, 20]. Since neutralizing antibody titers in SARS-COV-2infected individuals varied widely, the EUROIMMUNanti-SARS-CoV-2 IgA and IgG assay could be considered for pre-screenings to determine optimal donors for convalescent plasma or estimating the induction of virusspecific neutralizing antibodies after vaccination.

Calculation of sensitivity of all commercially available test systems was performed with the NT as reference for past SARS-CoV-2 infection. As $5.7 \%$ of hospitalized COVID-19 patients do not generate neutralizing antibodies neither at the time of discharge nor thereafter [23], we could not exclude the possibility that we potentially missed some SARS-CoV-2-infected individuals. Moreover, since we included volunteers from a high-risk area in this small sample study, the data might not be representative for a low-prevalence setting, which is the current situation in most areas of Europe.

In conclusion, the four commercially available highthroughput assays for the detection of SARS-CoV-2-specific antibodies differed in their sensitivity and their potential to predict the neutralization capacity of patient sera. The $\mathrm{N}$ immunoassays tested here seemed to be more sensitive compared to S1 spike protein assays. However, sensitivity of the here described commercial SARS-CoV-2 antibody assays was insufficient for detection of all individuals that were shown to have neutralizing anti-SARS-CoV-2 antibodies. These results should be considered in future populationbased seroprevalence studies.

Supplementary Information The online version contains supplementary material available at https://doi.org/10.1007/s10096-021-04169-7.

Acknowledgements We thank all participants who donated blood for this study. 
Code availability Not applicable.

Author contribution Study design: FB, FK, HS, JT, and TS; conducting experiments and acquiring data: LM, PNO, RK; VDC, DFH, and TS; analyzing data: LM, PNO, AW, and TS; sample collection: TW, AM, VK, ID, and TS; development and implementation of serological testing: $\mathrm{OA}, \mathrm{SH}, \mathrm{MA}$, and NL; TS wrote the manuscript with support from NL, AW, LM, PNO, and JT. All authors read and critically revised the manuscript.

Funding Open Access funding enabled and organized by Projekt DEAL. This study was funded by the Jürgen Manchot Foundation and the HeinzAnsmann Foundation for AIDS research.

Data availability The data supporting the findings of this study are available within the article and its supplementary material.

\section{Declarations}

Ethics approval and consent to participate The study was approved by the local ethics committee (study number: 5350). Written informed consent was given from each included individual.

Consent for publication Not applicable.

Competing interests The authors declare no competing interests.

Open Access This article is licensed under a Creative Commons Attribution 4.0 International License, which permits use, sharing, adaptation, distribution and reproduction in any medium or format, as long as you give appropriate credit to the original author(s) and the source, provide a link to the Creative Commons licence, and indicate if changes were made. The images or other third party material in this article are included in the article's Creative Commons licence, unless indicated otherwise in a credit line to the material. If material is not included in the article's Creative Commons licence and your intended use is not permitted by statutory regulation or exceeds the permitted use, you will need to obtain permission directly from the copyright holder. To view a copy of this licence, visit http://creativecommons.org/licenses/by/4.0/.

\section{References}

1. Zhou P, Yang X-L, Wang X-G, Hu B, Zhang L, Zhang W, Si H-R, Zhu Y, Li B, Huang C-L, Chen H-D, Chen J, Luo Y, Guo H, Jiang R-D, Liu M-Q, Chen Y, Shen X-R, Wang X, Zheng X-S, Zhao K, Chen Q-J, Deng F, Liu L-L, Yan B, Zhan F-X, Wang Y-Y, Xiao GF, Shi Z-L (2020) A pneumonia outbreak associated with a new coronavirus of probable bat origin. Nature 579(7798):270-273. https://doi.org/10.1038/s41586-020-2012-7

2. Gorbalenya AE, Baker SC, Baric RS, de Groot RJ, Drosten C, Gulyaeva AA, Haagmans BL, Lauber C, Leontovich AM, Neuman BW, Penzar D, Perlman S, LLM P, Samborskiy DV, Sidorov IA, Sola I, Ziebuhr J, Coronaviridae Study Group of the International Committee on Taxonomy of V (2020) The species severe acute respiratory syndrome-related coronavirus: classifying 2019-nCoV and naming it SARS-CoV-2. Nat Microbiol 5(4):536544. https://doi.org/10.1038/s41564-020-0695-z

3. COVID 19 Pandemic Emergency Information (2020) https:// covid19.who.int/
4. Whitman JD, Hiatt J, Mowery CT, Shy BR, Yu R, Yamamoto TN, Rathore U, Goldgof GM, Whitty C, Woo JM, Gallman AE, Miller TE, Levine AG, Nguyen DN, Bapat SP, Balcerek J, Bylsma SA, Lyons AM, Li S, Wong AW, Gillis-Buck EM, Steinhart ZB, Lee Y, Apathy R, Lipke MJ, Smith JA, Zheng T, Boothby IC, Isaza E, Chan J, Acenas DD 2nd, Lee J, Macrae TA, Kyaw TS, Wu D, Ng DL, Gu W, York VA, Eskandarian HA, Callaway PC, Warrier L, Moreno ME, Levan J, Torres L, Farrington LA, Loudermilk RP, Koshal K, Zorn KC, Garcia-Beltran WF, Yang D, Astudillo MG, Bernstein BE, Gelfand JA, Ryan ET, Charles RC, Iafrate AJ, Lennerz JK, Miller S, Chiu CY, Stramer SL, Wilson MR, Manglik A, Ye CJ, Krogan NJ, Anderson MS, Cyster JG, Ernst JD, AHB W, Lynch KL, Bern C, Hsu PD, Marson A (2020) Evaluation of SARS-CoV-2 serology assays reveals a range of test performance. Nat Biotechnol. https://doi.org/10.1038/s41587-0200659-0

5. Krammer F, Simon V (2020) Serology assays to manage COVID19. Science eabc1227. https://doi.org/10.1126/science.abc1227

6. Walker A, Houwaart T, Wienemann T, Kohns Vasconcelos M, Strelow D, Senff T, Hülse L, Adams O, Andree M, Hauka S, Feldt T, Jensen B-E, Keitel V, Kindgen-Milles D, Timm J, Pfeffer K, Dilthey AT (2020) Genetic structure of SARS-CoV-2 in Western Germany reflects clonal superspreading and multiple independent introduction events. medRxiv: 2020.2004.2025.20079517. doi:https://doi.org/10.1101/2020.04. 25.20079517

7. Gauger PC, Vincent AL (2014) Serum virus neutralization assay for detection and quantitation of serum-neutralizing antibodies to influenza A virus in swine. Methods Mol Biol 1161:313-324. https:// doi.org/10.1007/978-1-4939-0758-8_26

8. RKI (2020) Coronavirus Disease 2019 (COVID-19) Daily Situation Report of the Robert Koch Institute 04/03/2020

9. Kohmer N, Westhaus S, Rühl C, Ciesek S, Rabenau HF Clinical performance of different SARS-CoV-2 IgG antibody tests. J Med Virol n/a (n/a). https://doi.org/10.1002/jmv.26145

10. Nisreen MAO, Marcel AM, Wentao L, Chunyan W, Corine HG, Victor MC, Mart ML, Reina SS, de Erwin B, Felicity DC, Yazdan Y, Le Quentin H, Diane D, Nadhira H-F, Chantal BEMR, BerendJan B, Christian D, Marion PGK, Bart LH (2020) Severe acute respiratory syndrome coronavirus $2-$ specific antibody responses in coronavirus disease 2019 patients. Emerg Infect Dis J 26(7). https://doi.org/10.3201/eid2607.200841

11. Zhao J, Yuan Q, Wang H, Liu W, Liao X, Su Y, Wang X, Yuan J, Li T, Li J, Qian S, Hong C, Wang F, Liu Y, Wang Z, He Q, Li Z, He B, Zhang T, Fu Y, Ge S, Liu L, Zhang J, Xia N, Zhang Z (2020) Antibody responses to SARS-CoV-2 in patients of novel coronavirus disease 2019. Clin Infect Dis. https://doi.org/10.1093/cid/ ciaa344

12. Long Q-X, Liu B-Z, Deng H-J, Wu G-C, Deng K, Chen Y-K, Liao P, Qiu J-F, Lin Y, Cai X-F, Wang D-Q, Hu Y, Ren J-H, Tang N, Xu Y-Y, Yu L-H, Mo Z, Gong F, Zhang X-L, Tian W-G, Hu L, Zhang X-X, Xiang J-L, Du H-X, Liu H-W, Lang C-H, Luo X-H, Wu S-B, Cui X-P, Zhou Z, Zhu M-M, Wang J, Xue C-J, Li X-F, Wang L, Li Z-J, Wang K, Niu C-C, Yang Q-J, Tang X-J, Zhang Y, Liu X-M, Li J-J, Zhang D-C, Zhang F, Liu P, Yuan J, Li Q, Hu J-L, Chen J, Huang A-L (2020) Antibody responses to SARS-CoV-2 in patients with COVID-19. Nat Med. https://doi.org/10.1038/s41591-0200897-1

13. Choe PG, Kang CK, Suh HJ, Jung J, Kang E, Lee SY, Song KH, Kim HB, Kim NJ, Park WB, Kim ES, Oh MD (2020) Antibody responses to SARS-CoV-2 at 8 weeks postinfection in asymptomatic patients. Emerg Infect Dis 26(10):2484-2487. https://doi.org/ 10.3201/eid2610.202211

14. Lou B, Li TD, Zheng SF, Su YY, Li ZY, Liu W, Yu F, Ge SX, Zou QD, Yuan Q, Lin S, Hong CM, Yao XY, Zhang XJ, Wu DH, Zhou GL, Hou WH, Li TT, Zhang YL, Zhang SY, Fan J, Zhang J, Xia 
NS, Chen Y (2020) Serology characteristics of SARS-CoV-2 infection after exposure and post-symptom onset. Eur Respir J 56(2). https://doi.org/10.1183/13993003.00763-2020

15. Fontanet A, Tondeur L, Madec Y, Grant R, Besombes C, Jolly N, Fernandes Pellerin S, Ungeheuer M-N, Cailleau I, Kuhmel L, Temmam S, Huon C, Chen K-Y, Crescenzo B, Munier S, Demeret C, Grzelak L, Staropoli I, Bruel T, Gallian P, Cauchemez S, van der Werf S, Schwartz O, Eloit M, Hoen B (2020) Cluster of COVID-19 in northern France: a retrospective closed cohort study. medRxiv:2020.2004.2018.20071134. https:// doi.org/10.1101/2020.04.18.20071134

16. Streeck H, Schulte B, Kuemmerer B, Richter E, Hoeller T, Fuhrmann C, Bartok E, Dolscheid R, Berger M, Wessendorf L, Eschbach-Bludau M, Kellings A, Schwaiger A, Coenen M, Hoffmann P, Noethen M, Eis-Huebinger A-M, Exner M, Schmithausen R, Schmid M, Hartmann G (2020) Infection fatality rate of SARS-CoV-2 infection in a German community with a super-spreading event. medRxiv:2020.2005.2004.20090076. https://doi.org/10.1101/2020.05.04.20090076

17. Kohmer N, Westhaus S, Rühl C, Ciesek S, Rabenau HF (2020) Brief clinical evaluation of six high-throughput SARS-CoV-2 IgG antibody assays. J Clin Virol 129:104480. https://doi.org/10.1016/j. jcv.2020.104480

18. Burbelo PD, Riedo FX, Morishima C, Rawlings S, Smith D, Das S, Strich JR, Chertow DS, Davey RT Jr, Cohen JI (2020) Sensitivity in detection of antibodies to nucleocapsid and spike proteins of severe acute respiratory syndrome coronavirus 2 in patients with coronavirus disease 2019. J Infect Dis. https://doi.org/10.1093/infdis/ jiaa273

19. Grzelak L, Temmam S, Planchais C, Demeret C, Huon C, Guivel F, Staropoli I, Chazal M, Dufloo J, Planas D, Buchrieser J, Rajah MM, Robinot R, Porrot F, Albert M, Chen K-Y, Crescenzo B, Donati F, Anna F, Souque P, Gransagne M, Bellalou J, Nowakowski M, Backovic M, Bouadma L, Le Fevre L, Le Hingrat Q, Descamps D, Pourbaix A, Yazdanpanah Y, Tondeur L, Besombes C, Ungeheuer M-N, Mellon G, Morel P, Rolland S, Rey F, Behillil S, Enouf V, Lemaitre A, Creach M-A, Petres S, Escriou N,
Charneau P, Fontanet A, Hoen B, Bruel T, Eloit M, Mouquet H, Schwartz O, van der Werf S (2020) SARS-CoV-2 serological analysis of COVID-19 hospitalized patients, pauci-symptomatic individuals and blood donors. medRxiv:2020.2004.2021.20068858. https://doi.org/10.1101/2020.04.21.20068858

20. GeurtsvanKessel CH, Okba NMA, Igloi Z, Bogers S, Embregts CWE, Laksono BM, Leijten L, Rokx C, Rijnders B, RahamatLangendoen J, van den Akker JPC, van Kampen JJA, van der Eijk AA, van Binnendijk RS, Haagmans B, Koopmans M (2020) An evaluation of COVID-19 serological assays informs future diagnostics and exposure assessment. Nat Commun 11(1):3436. https://doi.org/10.1038/s41467-020-17317-y

21. Berry JD, Hay K, Rini JM, Yu M, Wang L, Plummer FA, Corbett CR, Andonov A (2010) Neutralizing epitopes of the SARS-CoV Sprotein cluster independent of repertoire, antigen structure or $\mathrm{mAb}$ technology. mAbs 2(1):53-66. https://doi.org/10.4161/mabs.2.1. 10788

22. Amanat F, Stadlbauer D, Strohmeier S, Nguyen THO, Chromikova V, McMahon M, Jiang K, Arunkumar GA, Jurczyszak D, Polanco J, Bermudez-Gonzalez M, Kleiner G, Aydillo T, Miorin L, Fierer DS, Lugo LA, Kojic EM, Stoever J, Liu STH, CunninghamRundles C, Felgner PL, Moran T, García-Sastre A, Caplivski D, Cheng AC, Kedzierska K, Vapalahti O, Hepojoki JM, Simon V, Krammer F (2020) A serological assay to detect SARS-CoV-2 seroconversion in humans. Nat Med. https://doi.org/10.1038/ s41591-020-0913-5

23. Wu F, Wang A, Liu M, Wang Q, Chen J, Xia S, Ling Y, Zhang Y, Xun J, Lu L, Jiang S, Lu H, Wen Y, Huang J (2020) Neutralizing antibody responses to SARS-CoV-2 in a COVID-19 recovered patient cohort and their implications. medRxiv: 2020.2003.2030.20047365.https://doi.org/10.1101/2020.03.30. 20047365

Publisher's note Springer Nature remains neutral with regard to jurisdictional claims in published maps and institutional affiliations. 